\title{
Parameters for embryo development in vitro: The role of the WHO guidelines (2010) in the characterization of abnormal sperm
}

\author{
Parâmetros para o desenvolvimento embrionário in vitro. O papel da \\ normatização da Organização Mundial de Saúde (2010) na classificação \\ de sêmen anormal
}

Edson Borges Jr., M.D., Ph.D. a,b, Amanda Souza Setti, M.Sc. ${ }^{a}$, Daniela Paes de Almeida Ferreira Braga, M.Sc. ${ }^{a}, b$,

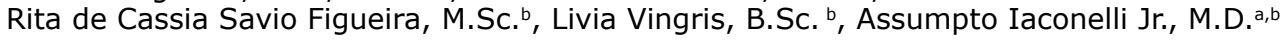

\begin{abstract}
RESUMO
Introdução: $O$ papel dos fatores paternos no desenvolvimento embrionário permanece controverso. Além disso, não está claro se os novos valores de referência para os parâmetros seminais se correlacionam com os resultados de ICSI. O objetivo deste estudo foi determinar se a avaliação dos parâmetros seminais de acordo com os novos valores de referência da OMS está associada à incidência de embriões de boa qualidade e aos resultados do ciclo de ICSI.

Métodos: Um total de 385 ciclos foram incluído e dividido em dois grupos de acordo com a qualidade seminal: grupo parâmetros seminais anormais (grupo ASP, $\mathrm{n}=175$ ) e grupo parâmetros seminais normais (grupo NSP, $\mathrm{n}=$ 210). Os resultados de ICSI foram comparados entre os grupos. Modelos de análise de regressão foram utilizados para avaliar a influência dos parâmetros seminais sobre os embriões de boa qualidade e resultados de ICSI.

Resultados: Apenas a motilidade espermática influenciou positivamente a taxa de embriões de boa qualidade (RC: $0.139, p=0.042$ ).

Conclusão: Este estudo demonstrou que a motilidade progressiva espermática influencia positivamente a qualidade embrionária. Os valores de referência recentemente estabelecidos para características do sêmen são de valor limitado na previsão de desenvolvimento embrionário.

Palavras-chave: parâmetros seminais e OMS; qualidade embrionária e OMS; motilidade espermática e OMS.
\end{abstract}

\begin{abstract}
Introduction: The role of paternal factors in embryonic development remains controversial. Moreover, it is unclear whether the new reference values for semen parameters correlate with ICSI outcomes. The objective of this study was to determine whether the assessment of sperm parameters according to the new reference values is associated with the frequency of high-quality embryos and ICSI cycle outcomes. Materials and Methods: A total of 385 cycles was included and classified as abnormal sperm parameter group (ASP group, $\mathrm{n}=175$ ) and normal sperm parameter group (NSP group, $n=210$ ). The ICSI outcomes were then compared between the groups. Regression analysis models were performed to evaluate the influence of semen parameters on high-quality embryos and the ICSI outcomes.

Results: Only sperm motility positively influenced the high-quality embryo rate (RC: $0.139, \mathrm{p}=0.042$ ).

Conclusion: This study demonstrated that sperm progressive motility positively influence the embryo quality rate. The recently established reference values for semen characteristics are of limited value in predicting embryonic development. Key words: sperm parameters and $\mathrm{WHO}$; embryo quality and WHO; sperm motility and WHO.
\end{abstract}

\section{INTRODUCTION}

It is estimated that one in seven couples will experience fertility issues throughout their reproductive lives. The male factor, which is the single most common cause of infertility, is solely responsible in $30 \%$, and is contributory in an additional $30 \%$, of the cases (Smit et al., 2010; Trost \& Nehra, 2011). Traditionally, the evaluation of male fertility potential has relied upon microscopic assessments to determine semen quality (Merchant et al., 2011). The most important conventional parameters, such as the concentration, motility and morphology of the sperm in the ejaculate, have been recommended by the World Health Organization (WHO) (WHO, 1999). The WHO recently updated their laboratory manual for the examination of human semen in 2010, with modifications to the reference values (WHO, 2010). In vitro fertilization (IVF) using intracytoplasmic sperm injection (ICSI) is the most indicated treatment to overcome male factor infertility (Donnelly et al., 1998). However, some characteristics are still considered important for the clinical outcomes of ICSI (Lee et al., 2009).

It is now well established that the spermatozoon does not merely carry genetic material to the oocyte. The human spermatozoon is crucial for contributing three components: (i) the paternal genome, (ii) the signal to initiate oocyte activation and (iii) the centriole, which participates in the initial development of the zygote (Barroso et al., 2009). Therefore, ICSI has created concerns over the possibility of a paternal influence because the fertilizing spermatozoa have a highly dynamic and essential participation in embryogenesis and may be a determinant of compromised embryo development (Sakkas et al., 1996; Lopes et al., 1998; Host et al., 2000; Morris et al., 2002; Barroso et al., 2009).

The role of paternal factors in embryonic development remains controversial. Moreover, it is unclear whether the new reference values for semen parameters correlate with ICSI outcomes. Therefore, the objectives of the present study were to determine whether the critical assessment of sperm parameters according to the new reference values during the ICSI semen analysis is associated with the rate of high-quality embryos and ICSI cycle outcomes

\section{METHODS}

Experimental design, patients and inclusion criteria To evaluate more objectively the potential adverse effects of abnormal sperm parameters on embryo quality and other ICSI outcomes, such as fertilization, implantation, pregnancy and miscarriage rates, ICSI cycles that met the following criteria were selected in this cohort study: injection of freshly ejaculated sperm, day 3 embryo transfer, female age $\leq 37$ years and the number of retrieved oocytes $\geq 6$. A total of 385 ICSI cycles, performed between January 2010 and June 2011, was selected for inclusion in the study.

In addition, ICSI cycles with any female factors other than a tubal factor were also excluded from this study because female factors may significantly influence the oocyte quality, preimplantation embryo development, and/or implantation. Ejaculated sperm samples were evaluated according to the WHO criteria (WHO, 2010).

In the first analysis, the patients were classified into an abnormal sperm parameter group (ASP group, $n=175$ ) and
Recebido em 21-03-2013

Aceito em 22-07-2013
Copyright - Todos os direitos reservados a

SBRA - Sociedade Brasileira de Reprodução Assistida 
a normal sperm parameter group (NSP group, $n=210$ ). The ASP group included patients with $<15$ million sperm per $\mathrm{mL}$ and/or $<40 \%$ motility and/or $<32 \%$ progressive motility and/or $<4 \%$ morphologically normal forms. The ICSI outcomes were compared between these groups. In the second analysis, the influences of sperm parameters on the high-quality embryos rate and ICSI outcomes were assessed.

A written informed consent was obtained in which the patients agreed to share the outcomes of their own cycles for research purposes, and the study was approved by the local Institutional Review Board.

\section{Controlled ovarian stimulation}

Ovarian stimulation was achieved by the administration of a recombinant follicle-stimulating hormone ( $r-F S H$, Gonal- $\mathrm{F}^{\circledR}$, Serono, Geneva, Switzerland) and gonadotropin-releasing hormone (GnRH) antagonist, cetrorelix acetate (Cetrotide; Serono Laboratories, Geneva, Switzerland). Oocyte retrieval was performed 35 hours after the administration of hCG through transvaginal ultrasonography.

\section{Semen analysis and preparation}

All of the semen samples were collected in the laboratory after 3 to 5 days of ejaculatory abstinence. After liquefaction for 30 minutes at room temperature, the semen samples were evaluated according to the threshold values established by the WHO (WHO, 2010). Sperm count and motility assessment were performed following the instructions of the counting chamber manufacturer (Makler counting chamber, Sefi Medical Instruments, Haifa, Israel). The counting chamber was heated at $37^{\circ} \mathrm{C}$ in a heating stage prior to use. The sample was homogenized, by moving gently in the container, and a volume of 3-5 $\mu \mathrm{l}$ of semen sample was transferred to the center of the chamber. Sperm count was performed in 10 squares of the chamber. The total sperm count is the end concentration expressed as $10^{6}$ sper$\mathrm{matozoa} / \mathrm{ml}$. Sperm motility was assessed in 100 random spermatozoa by characterizing them as (i) grade A (rapid progressive motility), grade B (progressive motility), grade C (non progressive motility) and grade $D$ (immotile) and the motility was expressed as percentages. Sperm morphology was evaluated on air-dried smears, fixed and stained by the quick-stain technique (Diff-Quick; Quick-Panoptic, Amposta, Spain). A total of 200 sperm cells was characterized as morphologically normal or abnormal and the final morphology was expressed as percentages. A density gradient centrifugation technique was used for the sperm preparation. Using a sterile pipette $1.0 \mathrm{ml}$ of the "lower layer" (90\% Isolate, Irvine Scientific, Santa Ana, CA, USA) was transferred into a conical centrifuge tube. Using a new sterile pipette $1.0 \mathrm{~mL}$ of the "upper layer" (50\% Isolate, Irvine Scientific, Santa Ana, CA, USA) was gently dispensed on top of the lower layer. A liquefied $2.0 \mathrm{ml}$ semen sample was then placed on top of the upper layer and the tube was centrifuged for 20 minutes at $330 \times g$ and this process was repeated using additional tubes until the whole ejaculated sample was processed. The upper and lower layers were carefully aspirated without disturbing the pellet. Using a transfer pipette, $1.0 \mathrm{ml}$ of HEPES-buffered human tubal fluid medium (mHTF, Global, Life Global, Connecticut, USA) was added and the re-suspended pellet was centrifuged for 7 minutes at $330 \times g$. The washing procedure was repeated. The supernatant was then removed and the pellet suspended in a volume of $0.5 \mathrm{ml}$ of $\mathrm{mHTF}$. Sperm count and motility were estimated in the recovered fractions.

\section{ICSI, embryo quality and transfer}

ICSI was performed according to Palermo et al (Palermo et al., 1992). Approximately 16 hours after ICSI, fertilization was confirmed by the presence of two pronuclei and the extrusion of the second polar body. The embryos were kept in a 50-uL drop of culture medium (Global ${ }^{\circledR}$, Life Global, Connecticut, USA) supplemented with $10 \%$ protein supplement and covered with paraffin oil in a humidified atmosphere under $6 \% \mathrm{CO}_{2}$ at $37{ }^{\circ} \mathrm{C}$ for three days.

High-quality embryos were defined as those showing 8-10 cells on the third day of development, less than $15 \%$ fragmentation, symmetric blastomeres, an absence of multinucleation and an absence of zona pellucida dysmorphisms. Embryo transfer was performed on day 3 using a soft cathe- ter with transabdominal ultrasound guidance. One to three embryos were transferred per patient.

Clinical follow-up

A pregnancy test was performed 12 days after embryo transfer. All of the women with a positive test had a transvaginal ultrasound scan 2 weeks after the positive test. A clinical pregnancy was diagnosed when a fetal heartbeat was detected. The clinical pregnancy rates were calculated per transfer, and miscarriage was defined as spontaneous abortion before 20 weeks of gestation.

\section{Statistical analysis}

The mean values \pm standard deviations (SD) were used for the continuous variables and were compared using Student's $t$ parametric test or Mann-Whitney non-parametric test. The percentages were used for the categorical variables and were compared using the Chi-squared or Fisher exact test only when the expected frequency was five or fewer.

Linear regression was used to evaluate the influence of semen parameters on the frequency of high-quality embryos and implantation rate (continuous variables), whereas binary regression was used to investigate the influence on pregnancy rate (categorical variable). All regression analysis models were adjusted for the maternal age.

The results were considered to be significant at the $5 \%$ critical level $(p<0.05)$ and were expressed as regression coefficients (RC), standard errors (SE) and $\mathrm{R}^{2}$, or odds ratios (OR), with $95 \%$ confidence intervals (CI) and $p$ values. The data analyses were conducted using MINITAB 16 Software.

\section{RESULTS}

A total of 385 ICSI cycles was included in this study. The patients' demographics, stimulation and cycle characteristics for the ASP and NSP groups are shown in Table 1 . There were no significant differences between the two groups.

Table 1. Patients' demographics, stimulation and cycle characteristics for the ASP and NSP groups

\begin{tabular}{lcccc}
\hline Variable & $\begin{array}{c}\text { ASP group } \\
(\mathbf{n = 1 7 5})\end{array}$ & $\begin{array}{c}\text { NSP group } \\
(\mathbf{n = 2 1 0})\end{array}$ & $\begin{array}{c}\boldsymbol{P} \\
\text { value }\end{array}$ \\
\hline Female age & $32,09 \pm 2,49$ & $32,39 \pm 2,55$ & 0,237 \\
\hline Male age & $35,65 \pm 5,62$ & $35,29 \pm 4,64$ & 0,500 \\
\hline $\begin{array}{l}\text { Dose of FSH administe- } \\
\text { red (mean } \pm \text { SD) }\end{array}$ & $2010 \pm 565$ & $2120 \pm 609$ & 0,069 \\
\hline $\begin{array}{l}\text { Estradiol level (pg/mL) } \\
\text { (mean } \pm \text { SD) }\end{array}$ & $2386 \pm 1775$ & $2381 \pm 2024$ & 0,982 \\
\hline $\begin{array}{l}\text { Number of follicles } \\
\text { (mean } \pm \text { SD) }\end{array}$ & $23,6 \pm 12,2$ & $22,0 \pm 14,4$ & 0,218 \\
\hline $\begin{array}{l}\text { Number of oocytes } \\
\text { (mean } \pm \text { SD) }\end{array}$ & $16,53 \pm 8,83$ & $15,35 \pm 9,08$ & 0,199 \\
\hline $\begin{array}{l}\text { Number of MII oocytes } \\
\text { (mean } \pm \text { SD) }\end{array}$ & $11,86 \pm 6,70$ & $11,34 \pm 7,16$ & 0,463 \\
\hline MII oocyte rate (\%) & 73,5 & 74,2 & 0,685 \\
\hline Semen volume (mL) & $3,38 \pm 1,72$ & $3,43 \pm 2,19$ & 0,801 \\
\hline $\begin{array}{l}\text { Sperm concentration } \\
\text { (million/mL) }\end{array}$ & $8,8 \pm 11,5$ & $42,1 \pm 22,7$ & $<0,001$ \\
\hline Sperm motility (\%) & $42,2 \pm 17,5$ & $67,5 \pm 10,9$ & $<0,001$ \\
\hline $\begin{array}{l}\text { Progressive sperm moti- } \\
\text { lity (\%) }\end{array}$ & $29,7 \pm 18,8$ & $53,4 \pm 11,2$ & $<0,001$ \\
\hline $\begin{array}{l}\text { Normal sperm morpho- } \\
\text { logy (\%) }\end{array}$ & $3,1 \pm 2,2$ & $4,3 \pm 3,6$ & $<0,001$ \\
\hline Fertilization rate (\%) & 74,6 & 75,6 & 0,570 \\
\hline $\begin{array}{l}\text { High-quality embryos } \\
\text { rate (\%) }\end{array}$ & 43,6 & 44,7 & 0,716 \\
\hline $\begin{array}{l}\text { Transferred embryos } \\
\text { (mean } \pm \text { SD) }\end{array}$ & 1,77 & 1,80 & 0,719 \\
\hline Implantation rate (\%) & 35,4 & 28,7 & 0,117 \\
\hline Pregnancy rate (\%) & 48,19 & 40,30 & 0,129 \\
\hline Miscarriage rate (\%) & 11,25 & 14,81 & 0,502 \\
\hline ASP: & & \\
\hline
\end{tabular}

ASP: abnormal sperm parameters, NSP: normal sperm parameters, SD: standard deviation, MII: metaphase II. 
We observed that sperm concentration and morphology did not influence any of the ICSI outcomes. However, sperm motility positively influenced the high-quality embryo rate (RC: $0.139, R^{2}: 0.9, p=0.042$ ) (Table 2).

Table 2. Influences of sperm parameters on ICSI outcomes

\begin{tabular}{|c|c|c|c|c|c|}
\hline $\begin{array}{l}\text { Response } \\
\text { Variable } \\
\end{array}$ & $\begin{array}{l}\text { Predictors } \\
\text { Variable }\end{array}$ & & & & \\
\hline \multirow[t]{4}{*}{$\begin{array}{l}\text { Fertilisation } \\
\text { rate }\end{array}$} & $\begin{array}{l}\text { Semen } \\
\text { parameters }\end{array}$ & & $\mathrm{RC}$ & $\mathrm{R}^{2}$ & $p$ \\
\hline & & $\begin{array}{l}\text { Concentra- } \\
\text { tion }\end{array}$ & 0.026 & 0.1 & 0.456 \\
\hline & & Motility & 0.003 & 0.0 & 0.932 \\
\hline & & Morphology & 0.012 & 0.0 & 0.898 \\
\hline \multirow[t]{4}{*}{$\begin{array}{l}\text { High-quality } \\
\text { embryos rate }\end{array}$} & $\begin{array}{l}\text { Semen } \\
\text { parameters }\end{array}$ & & $\mathrm{RC}$ & $\mathrm{R}^{2}$ & $p$ \\
\hline & & $\begin{array}{l}\text { Concentra- } \\
\text { tion }\end{array}$ & -0.015 & 0.0 & 0.784 \\
\hline & & Motility & 0.139 & 0.9 & 0.042 \\
\hline & & Morphology & 0.122 & 0.1 & 0.264 \\
\hline \multirow[t]{4}{*}{$\begin{array}{l}\text { Implantation } \\
\text { rate }\end{array}$} & $\begin{array}{l}\text { Semen } \\
\text { parameters }\end{array}$ & & $\mathrm{RC}$ & $\mathrm{R}^{2}$ & $p$ \\
\hline & & $\begin{array}{l}\text { Concentra- } \\
\text { tion }\end{array}$ & -0.091 & 0.3 & 0.307 \\
\hline & & Motility & -0.078 & 0.1 & 0.476 \\
\hline & & Morphology & -0.211 & 0.0 & 0.874 \\
\hline \multirow[t]{4}{*}{ Pregnancy } & $\begin{array}{l}\text { Semen } \\
\text { parameters }\end{array}$ & & OR & CI & $p$ \\
\hline & & $\begin{array}{l}\text { Concentra- } \\
\text { tion }\end{array}$ & 1.00 & $\begin{array}{c}0.99- \\
1.00 \\
\end{array}$ & 0.361 \\
\hline & & Motility & 1.00 & $\begin{array}{c}0.99- \\
1.01\end{array}$ & 0.815 \\
\hline & & Morphology & 0.98 & $\begin{array}{c}0.68- \\
1.09 \\
\end{array}$ & 0.822 \\
\hline \multirow[t]{4}{*}{ Miscarriage } & $\begin{array}{l}\text { Semen } \\
\text { parameters }\end{array}$ & & OR & CI & $p$ \\
\hline & & $\begin{array}{l}\text { Concentra- } \\
\text { tion }\end{array}$ & 1.01 & $\begin{array}{c}1.00- \\
1.03\end{array}$ & 0.117 \\
\hline & & Motility & 1.01 & $\begin{array}{c}0.99- \\
1.03 \\
\end{array}$ & 0.573 \\
\hline & & Morphology & 1.02 & $\begin{array}{c}0.98- \\
1.11\end{array}$ & 0.911 \\
\hline
\end{tabular}

RC: Regression coefficient, OR: odds ratio, CI: confidence intervals.

The high-quality embryo rate was not influenced by male or female age, total dose of FSH administered, estradiol levels on the day of hCG administration, the number of follicles and oocytes, oocyte retrieval rate, number of MII oocytes or MII oocyte rate. The influences of the patients' demographics and response to COS on the high-quality embryo rate are shown in Table 3.

\section{DISCUSSION}

In this study, we aimed at comparing the ICSI outcomes between couples presenting normal and abnormal sperm parameters. Moreover, we evaluated whether the new recommended reference values for sperm parameters influence the high-quality embryo rate in ICSI cycles. We also analyzed whether the high-quality embryo rate was influenced by the patient's demographics and response to COS.

Our results showed that the ICSI outcomes were similar between the ASP and NSP groups. Regarding the sperm parameters, our results demonstrated that progressive motility positively influenced the high-quality embryo rate. High-quality embryos, classified according to morphological assessment, are associated with higher implantation and pregnancy rates. However, apparently normal embryos are often placed into the uterus but fail to implant (Corcoran et al., 2005). Therefore, it is still not possible to predict which embryo will implant and develop into a healthy child.
Table 3. Influences of patients' demographics and response to $\operatorname{COS}$ on the high-quality embryos rate

\begin{tabular}{lccc}
\hline Variable & $\mathbf{R C}$ & $\mathbf{R}^{2}$ & $\boldsymbol{p}$ \\
\hline Female age & -0.3456 & 0.1 & 0.545 \\
\hline Male age & -0.1422 & 0.1 & 0.615 \\
\hline Total FSH administered & 0.0007 & 0.0 & 0.762 \\
\hline Estradiol levels & -0.0014 & 0.9 & 0.123 \\
\hline Number of follicles & 0.1592 & 0.6 & 0.136 \\
\hline Number of oocytes & 0.1372 & 0.2 & 0.392 \\
\hline Oocyte retrieval rate & -0.0077 & 0.2 & 0.351 \\
\hline Number of MII oocytes & 0.1716 & 0.2 & 0.407 \\
\hline MII oocyte rate & -0.038 & 0.1 & 0.648 \\
\hline Fertilization rate & 0.2181 & 1,7 & 0.010 \\
\hline
\end{tabular}

COS: controlled ovarian stimulation, RC: regression coefficient, MII: metaphase II.

Several structures present in the spermatozoon are pivotal for the accomplishment of fertilization and normal embryo development (Barroso et al., 2009). The initial divisions of the recently formed zygote depend upon the machinery of the oocyte. A major expression of sperm-derived genes begin at the 8-cell stage; therefore, the effects of sperm nuclear alterations are usually not detected before the $3^{\text {rd }}$ day of embryo development. On the other hand, sperm cytoplasm deficiencies can be detected as early as the pronuclear stage and then throughout the preimplantation development. The terms "late" and "early" paternal effects have been proposed to refer to these two pathological conditions. The early paternal effect may include sperm deficiencies linked to oocyte activation and abnormalities of the centrosome-cytoskeletal apparatus (Barroso et al., 2009).

As early as 1887 , it was postulated that a mature oocyte contains all of the elements necessary for embryonic development, with the exception of the centrosome (Palermo et al., 1997). The centrosome, the most important contribution of the sperm cell to the zygote, is responsible for the formation of the mitotic spindle (Hinduja et al., 2010) and controls first mitotic divisions after fertilization (Schatten, 2008). Asch et al. (1995) demonstrated that centrosomal defects might lead to disorders in fertilization and early embryonic development. Accordingly, Terada et al. (2004) demonstrated that the sperm astef formation rate was lower in infertile men, compared to the controls, and correlated with the embryonic cleavage rate after IVF, suggesting that reproductive success during the first cell cycle requires a functional sperm centrosome.

Interestingly, the sperm centrosome is located in the midpiece of the sperm tail; therefore, it is likely that any abnormality in the centrosome would result in impaired sperm motility (Hinduja et al., 2010). More recently, Hinduja et al. (2010) investigated whether there was any difference in the sperm centrosomal proteins in normozoospermic and oligoasthenozoospermic (OA) patients. Their results demonstrated lower levels of $a-$ and $y$-tubulin in OA patients, compared to normal patients. The study suggests that $\mathrm{Y}$-tubulin is important for aiding in the motility of spermatozoa.

We observed that progressive motility positively influences the high-quality embryo rate. Thus, our results might provide corroborative evidence that abnormal centrosomal function compromises both sperm motility and early embryo development.

On the other hand, it has been previously demonstrated that sperm motility may also be a physiological marker 
for DNA integrity (Ramos \& Wetzels, 2001). Muratori et al. (2000) et al showed that sperm DNA fragmentation is associated with motility defects. Similarly, Varghese et al. (2009) observed a significant correlation between DNA integrity and sperm motility. Moreover, the authors noted a significant difference in acridine orange (test for evaluation of sperm DNA) levels between donors and patients with asthenozoospermia.

Sperm morphology is believed to be an important parameter in evaluating sperm quality (Van Waart et al., 2001). However, many studies, including the present work, have not observed correlations between embryo development and sperm morphology (Kupker et al., 1995; Mansour et al., 1995; Nagy et al., 1995). The most likely explanation for this is that prior to the ICSI, the best "normal-looking" spermatozoa is selected by the embryologist; thus, the oocyte is fertilized by a spermatozoon that may not be representative of the sperm population within the entire sample. However, the sperm selected may not always reflect the quality of the spermatozoa injected.

Our results showed no influence of maternal and paternal age on the high-quality embryo rate. Conversely, in the review article by Dain et al. (2011), paternal age was not found to affect embryo quality at the cleavage stage, but a significant decrease in blastocyst formation was associated with increased paternal age, probably reflecting male genomic activation within the embryo. With regards to maternal age, one study showed that increased maternal age is associated with declining quality of human embryos (Janny \& Menezo, 1996). Moreover, the response to COS, such as the dose of FSH administered, estradiol level on the day of hCG administration, the number of follicles and oocytes, did not influence embryo development.

\section{CONCLUSION}

This study demonstrated that sperm progressive motility positively influence the embryo quality rate, which did not differ between patients presenting normal and abnormal sperm parameters according to the 2010 WHO guidelines. Although the WHO manual has a vital continuing role in raising the standards of andrology laboratories, normal ranges are of limited value in the management of infertile couples, and semen analysis has limited prognostic power for male subfertility and ICSI outcomes.

\section{Corresponding Author}

Edson Borges Jr., M.D., Ph.D.

E-mail: edson@fertility.com.br

Address: Av. Brigadeiro Luis Antonio, 4545.

Sao Paulo - SP, Brazil. Zip: 01401-002

Phone: 5511 3018-8181

\section{REFERENCES}

Asch R, Simerly C, Ord T, Ord VA, Schatten G. The stages at which human fertilization arrests: microtubule and chromosome configurations in inseminated oocytes which failed to complete fertilization and development in humans. Hum Reprod. 1995; 10:1897-906.

Barroso G, Valdespin C, Vega E, Kershenovich R, Avila R, Avendano $C$, Oehninger $S$. Developmental sperm contributions: fertilization and beyond. Fertil Steril. 2009;92:835-48.

Corcoran D, Fair T, Lonergan P. Predicting embryo quality: mRNA expression and the preimplantation embryo. Reprod Biomed Online. 2005;11:340-8.

Dain $L$, Auslander R, Dirnfeld M. The effect of paternal age on assisted reproduction outcome. Fertil Steril. 2011;95:1-8.

Donnelly ET, Lewis SE, McNally JA, Thompson W. In vitro fertilization and pregnancy rates: the influence of sperm motility and morphology on IVF outcome. Fertil Steril. 1998;70:305-14.

Hinduja I, Baliga NB, Zaveri K. Correlation of human sperm centrosomal proteins with fertility. J Hum Reprod Sci. 2010;3:95-101.

Host $E$, Lindenberg $S$, Smidt-Jensen S. The role of DNA strand breaks in human spermatozoa used for IVF and ICSI. Acta Obstet Gynecol Scand. 2000;79:559-63.
Janny L, Menezo YJ. Maternal age effect on early human embryonic development and blastocyst formation. Mol Reprod Dev. 1996;45:31-7.

Kupker W, al-Hasani S, Schulze W, Kuhnel W, Schill T, Felberbaum $\mathrm{R}$, Diedrich K. Morphology in intracytoplasmic sperm injection: preliminary results. J Assist Reprod Genet. 1995;12:620-6.

Lee SH, Song H, Park YS, Koong MK, Song IO, Jun JH. Poor sperm quality affects clinical outcomes of intracytoplasmic sperm injection in fresh and subsequent frozen-thawed cycles: potential paternal effects on pregnancy outcomes. Fertil Steril. 2009;91:798-804.

Lopes S, Sun JG, Jurisicova A, Meriano J, Casper RF. Sperm deoxyribonucleic acid fragmentation is increased in poor-quality semen samples and correlates with failed fertilization in intracytoplasmic sperm injection. Fertil Steril. 1998;69:528-32.

Mansour RT, Aboulghar MA, Serour GI, Amin YM, Ramzi AM. The effect of sperm parameters on the outcome of intracytoplasmic sperm injection. Fertil Steril. 1995;64:982-6.

Merchant R, Gandhi G, Allahbadia GN. In vitro fertilization/intracytoplasmic sperm injection for male infertility. Indian J Urol. 2011;27:121-32.

Morris ID, Ilott S, Dixon L, Brison DR. The spectrum of DNA damage in human sperm assessed by single cell gel electrophoresis (Comet assay) and its relationship to fertilization and embryo development. Hum Reprod. 2002;17:990-8.

Muratori M, Piomboni P, Baldi E, Filimberti E, Pecchioli P, Moretti E, Gambera L, Baccetti B, Biagiotti R, Forti G et al. Functional and ultrastructural features of DNA-fragmented human sperm. J Androl. 2000;21:903-12.

Nagy ZP, Liu J, Joris H, Verheyen G, Tournaye H, Camus M, Derde MC, Devroey $P$, Van Steirteghem AC. The result of intracytoplasmic sperm injection is not related to any of the three basic sperm parameters. Hum Reprod. 1995;10:1123-9.

Palermo G, Joris H, Devroey P, Van Steirteghem AC. Pregnancies after intracytoplasmic injection of single spermatozoon into an oocyte. Lancet. 1992;340:17-8.

Palermo GD, Colombero LT, Rosenwaks Z. The human sperm centrosome is responsible for normal syngamy and early embryonic development. Rev Reprod. 1997;2:19-27.

Ramos $L$, Wetzels AM. Low rates of DNA fragmentation in selected motile human spermatozoa assessed by the TUNEL assay. Hum Reprod. 2001;16:1703-7.

Sakkas D, Urner F, Bianchi PG, Bizzaro D, Wagner I, Jaquenoud N, Manicardi G, Campana A. Sperm chromatin anomalies can influence decondensation after intracytoplasmic sperm injection. Hum Reprod. 1996;11:837-43.

Schatten $\mathrm{H}$. The mammalian centrosome and its functional significance. Histochem Cell Biol. 2008;129:667-86.

Smit M, Romijn JC, Wildhagen MF, Weber RF, Dohle GR. Sperm chromatin structure is associated with the quality of spermatogenesis in infertile patients. Fertil Steril. 2010;94:1748-52.

Terada Y, Nakamura S, Simerly C, Hewitson L, Murakami T, Yaegashi N, Okamura K, Schatten G. Centrosomal function assessment in human sperm using heterologous ICSI with rabbit eggs: a new male factor infertility assay. Mol Reprod Dev. 2004;67:360-5.

Trost LW, Nehra A. Guideline-based management of male infertility: Why do we need it? Indian J Urol. 2011;27:49-57.

Van Waart J, Kruger TF, Lombard CJ, Ombelet W. Predictive value of normal sperm morphology in intrauterine insemination (IUI): a structured literature review. Hum Reprod Update. 2001;7:495-500.

Varghese AC, Bragais FM, Mukhopadhyay D, Kundu S, Pal M, Bhattacharyya AK, Agarwal A. Human sperm DNA integrity in normal and abnormal semen samples and its correlation with sperm characteristics. Andrologia. 2009;41:207-15.

WHO, eds. WHO laboratory manual for the examination of human semen and sperm-cervical mucus interaction. Cambridge, UK: Published on behalf of the World Health Organization by Cambridge University Press; 1999.

WHO, eds. WHO laboratory manual for the examination and processing of human semen. Geneva: World Health Organization; 2010. 